Wojciech NOWIAK

DOI : $10.14746 / p p .2018 .23 .4 .7$

Adam Mickiewicz University in Poznań

ORCID ID: https://orcid.org/0000-0001-7448-5002

Andrzej STELMACH

Adam Mickiewicz University in Poznań

ORCID ID: https://orcid.org/0000-0002-3747-0466

\title{
The cultural and social assimilation of immigrants, and systemic solutions - Poles in Norway and Ukrainians in Poland in the light of comparative research
}

\begin{abstract}
The article presents the problem of migration and assimilation of newcomers in the countries of residence. One of the main reasons for migration are economic and social considerations, this applies to both non-European arrivals and internal migration. The aim of this study, conducted by scholars from Norway and Poland, is to compare systemic solutions both within the social legislation and the functioning of the labor market with respect to Poles and Ukrainians, confronting them with existing barriers regarding the possibility of assimilation and obstacles related to the transformation of economic into settlement migration. The methodological and theoretical basis of the team's research is comparative methods, including comparative politics. The research on immigrants was conducted using both quantitative methods - statistical and qualitative data analysis - and research using the in-depth interview method. Poles and Ukrainians are not at the same stage of formal migration due to the formal plane. According to the analysis, Ukrainians have much greater opportunities for actual assimilation than Poles in Norway. Smaller cultural differences and linguistic barriers to the Ukrainians in Poland are conducive to this process. If the state and Polish society take advantage of this situation and enable the settlement of Ukrainians and make their job offers more attractive, there is a chance that they will fill the emerging demographic gap. It would be for the benefit of both societies.
\end{abstract}

Key words: migration, assimilation of immigrants, Poles in Norway, Ukrainians in Poland

\section{Introduction}

$T^{1}$ he problem of migration and assimilation of newcomers in the countries of residence has become the leading topic of both political and media debate in Europe. One of the main reasons for migration are economic and social considerations, this applies to both non-European arrivals and internal migration. One of the examples of internal migration of an economic nature is the migration of Poles after 2004 within the European Union and the European Economic Area. According to various data, about 2.5 million citizens emigrated from Poland, mainly for business purposes. One example of this migration is that of Poles migrating to Norway, who in a short space of time have become the second largest nationality in the country apart from Norwegians. In the case of this group, non-resident migration is still dominant - due to the formal and legal possibilities, among others, of gaining full social rights, which Poles can avail in Norway. The resulting gap on the Polish labor market is filled by employees from Ukraine. There are about 1.5-2 million of them in Poland. In this case, the motives for migration are also of an economic nature. At present, Ukrainians 
do not have analogous rights to those Poles have in Norway. This applies both to the labor market and economic migration itself. The aim of this study, conducted by scholars from Norway and Poland, is to compare systemic solutions both within the social legislation and the functioning of the labor market with respect to Poles and Ukrainians, confronting them with existing barriers regarding the possibility of assimilation and obstacles related to the transformation of economic into settlement migration. Comparing Norway's attractiveness for Poles and Poland's for Ukrainians is a matter of both interest and importance.

\section{The research methodology}

The basis of this article is the research undertaken by an international research team implementing the project titled Labor migration and the moral sustainability of the Norwegian welfare state funded by the Research Council of Norway as part of the Welfare, Working Life and Migration Program (Velferd, Arbeidsliv og Migrasjon - VAM) and similar surveys carried out in Poland with respect to Ukrainian citizens. The research in Poland was carried out from the resources of the Faculty of Political Science and Journalism and contained additional quantitative research based on the method of direct interview conducted at the beginning of 2018 on a group of 1,300 people. The research area in Norway was the Hardaland district, and in Poland - Wielkopolska. The methodological and theoretical basis of the team's research is comparative methods, including comparative politics (Landman, Robinson, 2009). The research on immigrants was conducted using both quantitative methods - statistical and qualitative data analysis - and research using the in-depth interview method (Weiss, 1995; Kvale, Brinkmann, 2009).

The study benefited from the snowball effect. As the number of people tested and the trust in the testers increased, subsequent people gave contacts to other respondents. Efforts were made to ensure that this selection was adequate to the situation of Poles in the Norwegian labor market and in the Polish immigrant group. An analogous rule was applied to Ukrainians in Poland.

The anonymity of the respondents was very important. Interviews and surveys were voluntary.

After conducting research in Norway, the areas of assimilation related to the social and cultural situation, access to services, norms and principles functioning in both communities, experiences exported by Poles from the country of origin were separated. Then, research was conducted on Ukrainians in Poland using the same assimilation planes for comparative analysis within assimilation.

\section{The socio-economic conditions and legal situation - Poles in Norway}

Already in the 19th century, Poland (Kaczmarek, 2008, p. 13) was one of the most important areas of net emigration in Europe. These were mainly labor migrations, some of them were transformed into settlement migrations. Very large migratory movements in relation to Poland took place after World War II, because at the end of the war, 5 million people were abroad, about $20 \%$ of all those who survived the war (Kersten, 1974, 
p. 320). An equally large wave of migration took place in the 1980s, according to available data, 2.2 million people emigrated from Poland during this period (Okólski, 1994, p. 25). This was related to the gradual abolition of restrictions and the socio-economic situation. Some emigrants left for political reasons.

Introducing the socio-economic determinants with regard to Poles living in Norway, one should bear in mind the fact that Polish citizens constituted one of the largest groups from Central and Eastern Europe who decided to migrate after the fall of the Iron Curtain, as well as the cessation of economic, military and political ties with the Soviet Union. For Poland, the transformation was symbolized by the national elections of June 4, 1989, in which the political opposition, mainly related to the Solidarity movement, was involved. The main motive for migration was economic, the desire to change the situation of their families who remained in the home country. Salary differences in Western European countries and Poland were very significant at that time.

Soon after, on January 1, 1992, the agreement on Poland's association with the EEC entered into force, which meant in practice the abolition of entry visas for Poles and made it possible to take up work. In the initial period, seasonal work was legally undertaken.

Before Poland's accession to the European Union, as a consequence of bilateral agreements concluded with Germany, France, Belgium and Switzerland, legal labor migration from Poland, including cross-border migration at the end of the 1990s, was around 300-400,000 people per year (Czop, 2013, pp. 34-44). The migration model, such as having a home and family in Poland and working abroad, had been created. The main directions of migration were Germany and the United States. People migrating from regions with large migration traditions often left their homeland. The migration of the 1980s and 90s was mainly short-term and was associated with taking up employment abroad, mainly in Western Europe, the USA and Canada.

The accession of Poland to the EU on May 1, 2004 was a breakthrough due to institutional changes in the migration of Poles. The European Union guaranteed workers' rights to newcomers from Poland, and the migration ceased to have its occasional nature. Norway, as one of the countries of the European Economic Area, experienced an immediate migration effect. As in other European countries, a new type of employment migration prevailed. In the initial period, Norway mostly took specialists and agricultural seasonal workers from Eastern Europe, and their number never exceeded several thousand annually (Brox, 2009). For the eight new EU member states of Poland, the Czech Republic, Hungary, Estonia, Latvia, Lithuania, Slovakia and Slovenia, transitional employment arrangements were in force in the years between 2004-2009 (NOU: 2011:7, p. 71). The consequences of being a member of the EU brought far-reaching, highly beneficial changes in terms of the possibility of using the social benefits available in Norway. Poles became part of the Norwegian welfare state overnight (Nowiak, 2011).

Under the existing solutions, they acquired rights to:

- equal treatment - citizens from the EEA from day one of their stay are treated in the same way and can enjoy the same rights as Norwegians;

- common benefits - everyone may exercise the rights acquired in other EEA countries in Norway. An example of this is pension benefits, where the Norwegian system requires a minimum of three years of employment to acquire rights. This must be a period of working in Norway; 
- proportionality - this means in practice that the recipient (pensioner) receives a partial benefit from the state from which he transferred to Norway;

- opportunities to export benefits - this means in practice that an employee from the EEA who acquires rights to benefits can obtain them thanks to permanent residence in Norway. An example is cash benefits, if the spouse and children of a Polish employee live in Poland, he/she gets a cash equivalent for not using the Norwegian kindergarten (Frieberg, 2013, p. 19). After the transition period, barriers concerning the employment of Poles in Norway were completely removed.

The research carried out in Norway on immigrants from Poland indicates that most of them came to work, which they sought while still in Poland. This was the result of the functioning of Polish and Norwegian employment offices (Frieberg, 2011). Poles, like citizens from other countries that joined the EU in 2004, worked mainly (as much as $77 \%$ ) in three sectors of the economy: agriculture, industry and construction. This situation changed slightly after 2010 , when women started to come to Norway and take up paid work. Other industries include cleaning services, trade, transport, hospitality, and public services, including health and social services. As for women, they mostly found their first employment in the cleaning industry, based on private contracts. This is undoubtedly related to the language barrier. Women do not work in large groups, as for instance men do in the construction industry, therefore knowledge of the language is the key prerequisite for them in order to get a job.

During the ten years of membership (2004-2014), the increase in the amount of Poles in Norway reached a level of $1,101 \%$, a greater increase was recorded only for Lithuanians 3,694\% (Aftenposten, 2014). In absolute numbers, according to data on January 1, 2015, immigrants and immigrant children with Polish roots accounted for 99,400 people, out of a total of 804,963 . This meant that Poles were the largest group, before Lithuanians - 39,300 and Swedes - 39,100 (Invandrere, 2015). Poles have become the dominant national group in this country among all immigrants to this country. It is difficult to estimate the final number of Poles staying and working in Norway, because, as research indicates, despite the possibility of legal employment, a group still works in the gray economy (Nowiak, Narożna, Cappelen, 2016).

Despite significant changes related to the development of Poland after joining the European Union, falling unemployment, higher salaries and an increasing standard of living, a very large percentage of Poles still harbor the desire to emigrate from Poland for economic reasons. According to the 2017 report by the Work Service, Labour Migration of Poles, $14 \%$ of professionally active people were prepared to leave Poland. This means that the number of Polish emigrants may increase to about 3.1 million people. The third country preferred by Poles after Germany (32\%) and Great Britain (19\%) is Norway (11\%) (Migracje Zarobkowe Polaków VII, 2017).

In the case of Poles leaving for work, it is very difficult to estimate the number of people who left Poland with the intention of taking up permanent residence, because the only indicator is the number of people resigning from permanent residence in Poland. As can be seen in the list below, in the peak year of 2006, the total was 46,936 people, while in 2017 it was only 11,888 . It can be concluded that a significant part of Poles who started working abroad, despite its multi-annual character, do not sever their family ties. In fact most of them plan to return. 
PP 4 '18 The cultural and social assimilation of immigrants, and systemic...

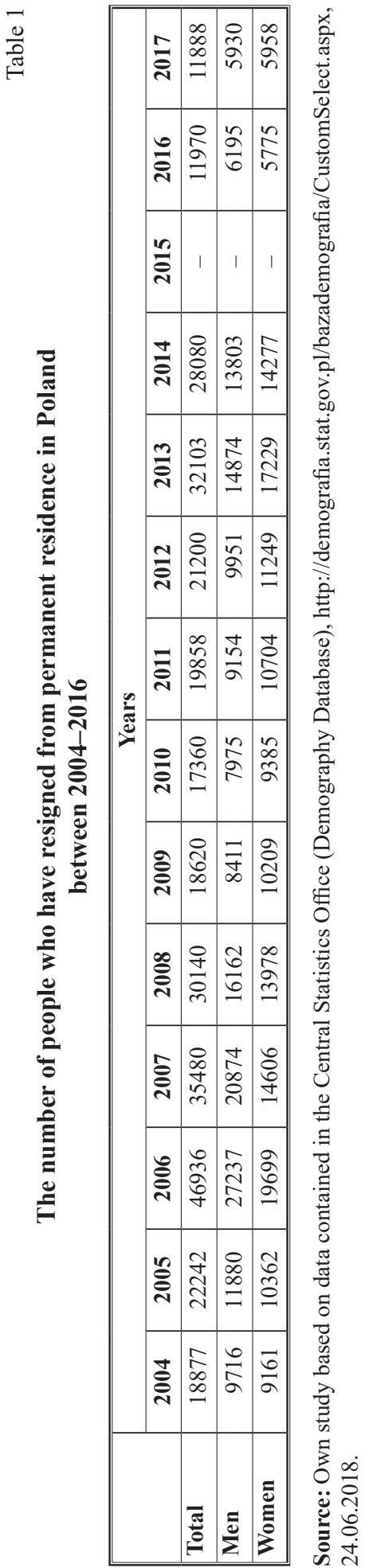


The largest increase in terms of permanent exits was noted in the first years of Poland's membership of the EU. After 2007, the number of people leaving the country with the intention of taking up permanent residence abroad has been systematically decreasing. In the initial period, a significant amount was the result of a process of family reunification, involving people who had previously left; and also the opportunity to benefit from equal social rights and travel by young people who saw the opportunity of a lifetime in the opening up of legal labor markets in the EU and the European Economic Area.

\section{Socio-economic conditions and legal situation - Ukrainians in Poland}

After proclaiming independence on August 24, 1991, and the formal breakup of the Soviet Union on December 26, 1991, Ukraine and its citizens found themselves in a similar situation as Poland. Citizens of Ukraine, under the Regulation of the Council of the European Union 539/2001, were included in Annex I (countries whose citizens need a visa to the Schengen area). This resulted in significant restrictions regarding the possibility of traveling to Poland.

After Poland's accession to the EU, Ukrainians, together with the citizens of Armenia, Belarus, Georgia, Moldova and the Russian Federation were subject to special procedural facilitations. They could take up work in Poland without the need to apply for a work permit. From 2007, they were allowed to work for three months in a six month period, and from 2008 for six months in a year. Similarly to Polish citizens, visas were abolished in 1992, so the breakthrough date for Ukraine was May 11, 2017, when the Council of the European Union adopted a regulation on visa liberalization for Ukrainian citizens coming to the EU for a period of 90 days in a six month period.

In practice, this meant the increasing attractiveness of other EU countries when it came to employing workers from Ukraine due to higher earnings for instance in Germany. Meanwhile, in Poland, certain areas of the economy could not do without employing Ukrainians. Without them, such sectors as retail, agri-food processing or the construction industry would be badly affected due to a lack of workers. Poland, bearing in mind the new situation, reacted to change the situation immediately. On July 20, 2017, under the new law on employment of foreigners from outside the EU for short-term and seasonal work, district employment offices registered approx. 1.8 million statements on the intention to employ foreigners, $85 \%$ of work permits and $95 \%$ of the statements went to citizens Ukraine. As of January 1, 2018, the rules of employing workers from Ukraine were simplified on the basis of a declaration on employing foreigners at the District Employment Office for a period of up to six months. Such a statement is entered in a register, on the basis of which a person staying under the visa-free regime can be legally employed or apply for a visa at the Consulate of the Republic of Poland in Ukraine, enabling legal stay in Poland. During the term of the contract, an employee from Ukraine has the same employment rights as a Polish citizen. Citizens of foreign countries, including of course Ukrainians who permanently reside in Poland, are subject to Polish social insurance. After three months of work by a foreigner as part of the declaration procedure, if the employer wants to continue cooperation with him based on a contract of employment and on conditions not worse than those specified in the statement, he may apply to the gov- 
ernor of region for a work permit (or a foreigner's application for a residence and work permits). Such permission is issued without the so-called labor market test. In this case, the foreigner has the right to legally perform work for the above-mentioned employer during the waiting period for the decision on the permit.

Seasonal work permits, which are given to all foreigners from non-EU/EEA countries, are issued by a district head or District Employment Offices acting on his behalf. This type of permit:

- entitles you to work for a period of nine months within one calendar year (cost PLN 30.00);

- when applying for this permission for citizens of Armenia, Belarus, Georgia, Moldova, Russia and Ukraine, it is not necessary to obtain information from a district head on the inability to satisfy personnel needs;

- concerns working in sectors regarded as seasonal;

- on the arrival of a foreigner in Poland, the employer is obliged to inform the District Employment Office and provide the foreigner's address - only after this does the office issue a seasonal work permit entitling the foreigner to work;

- in subsequent years of cooperation with a given foreigner, the employer can apply for so-called multi-season entry (up to three years);

- a foreigner may work while awaiting a seasonal work permit, i.e. after the entity informs the District Employment Office about the arrival of the foreigner. However, the work must be carried out under the conditions set out in the certificate of entry previously issued by the DEO;

- a a foreigner may also work while waiting for the extension of a seasonal work permit from the same employer;

- the employing entity is required to conclude a written contract with the foreigner and to present it beforehand with a translation into a language comprehensible to the foreigner in accordance with the conditions specified in the statement (the contract must include the conditions included in the declaration);

- the employing entity is obliged to comply with all obligations resulting from employment, just as in the case of Polish citizens.

As can be seen here, Poland wants to make work opportunities more attractive for employees from Ukraine, thus protecting itself against the mass departure of Ukrainians from Poland to the West. Probably some of them will be tempted by several times higher salaries, like in Germany, for instance. However, it should be remembered that they will not be able to work legally there, and the German inspection system in this area is very efficient.

According to the available data, $16 \%$ of Polish companies employ Ukrainians, and the largest enterprises hire them: we find them in $44 \%$ of large companies, $21 \%$ of medium-sized companies and $13 \%$ of small firms. Ukrainians are employed primarily in companies in the manufacturing industry (24\% of enterprises in this sector employ them), followed by the service sector (20\%) and trade (14\%). Earnings of workers from Ukraine are comparable to the level of earnings of Poles, which was primarily affected by raising the minimum wage in Poland to PLN 13.00 gross hourly pay. Citizens of Ukraine can often count on additions to salaries, such as accommodation, food, transport to and from the workplace, as well as social benefits. 
Employing a citizen of Ukraine to work, Polish entrepreneurs primarily use employment agencies (38\%). A further 35\% find workers through family and friends. Ukrainians, like other foreigners staying on the basis of a visa (national or Schengen), are not entitled to social assistance. They have full rights to education, education up to the age of eighteen is obligatory for foreigners, regardless of their status. When making statistical comparisons in relation to Poland, in terms of the number of immigrants, including citizens of Ukraine, we can clearly see a smaller influx of people with the intention of taking up permanent residence. This is undoubtedly associated with lower attractiveness of Poland compared to other EU and EEA countries.

Table 2

The number of people immigrating to Poland between 2004-2016

\begin{tabular}{|l|r|r|r|r|r|r|r|r|r|r|r|r|r|r|r||}
\hline & \multicolumn{10}{|c|}{ Years } \\
\cline { 2 - 16 } & $\mathbf{2 0 0 4}$ & $\mathbf{2 0 0 5}$ & $\mathbf{2 0 0 6}$ & $\mathbf{2 0 0 7}$ & $\mathbf{2 0 0 8}$ & $\mathbf{2 0 0 9}$ & $\mathbf{2 0 1 0}$ & $\mathbf{2 0 1 1}$ & $\mathbf{2 0 1 2}$ & $\mathbf{2 0 1 3}$ & $\mathbf{2 0 1 4}$ & $\mathbf{2 0 1 5}$ & $\mathbf{2 0 1 6}$ & $\mathbf{2 0 1 7}$ \\
\hline Total & 9485 & 9364 & 10802 & 14995 & 15275 & 17424 & 15246 & 15524 & 14583 & 12199 & 12330 & - & 13475 & 13324 \\
\hline Men & 4800 & 4873 & 5938 & 8503 & 8984 & 11145 & 9011 & 8863 & 8106 & 6854 & 6777 & - & 7299 & 7200 \\
\hline Women & 4695 & 4491 & 4864 & 6492 & 6291 & 6279 & 6232 & 6661 & 6477 & 5345 & 5553 & - & 6176 & 6124 \\
\hline
\end{tabular}

Source: Own study based on data contained in the Central Statistics Office (Demography Database), http:// demografia.stat.gov.pl/bazademografia/CustomSelect.aspx, 24.06.2018.

As for the citizens of Ukraine, they constitute only a small percentage of migrants with the intention of taking up permanent residence in Poland. This can be seen on the table below.

Table 3

The number of Ukrainian citizens immigrating to Poland between 2004-2016

\begin{tabular}{|c|c|c|c|c|c|c|c|c|c|c|c|c|c|c|}
\hline & \multicolumn{14}{|c|}{ Years } \\
\hline & 2004 & 2005 & 2006 & 2007 & 2008 & 2009 & 2010 & 2011 & 2012 & 2013 & 2014 & 2015 & 2016 & 2017 \\
\hline Total & 1196 & 1067 & 682 & 777 & 776 & 609 & 599 & 619 & 607 & 630 & 749 & - & 1351 & 1396 \\
\hline Men & 310 & 314 & 211 & 230 & 227 & 195 & 213 & 181 & 204 & 242 & 295 & - & 550 & 590 \\
\hline Women & 886 & 752 & 471 & 547 & 549 & 414 & 386 & 438 & 403 & 388 & 454 & - & 801 & 806 \\
\hline
\end{tabular}

Source: Own study based on data contained in the Central Statistics Office (Demography Database), http:// demografia.stat.gov.p1/bazademografia/CustomSelect.aspx, 24.06.2018.

Ukrainians are the dominant group when it comes to people who have been granted a positive decision for permanent residence by a regional governor in Poland. According to the data from the Office for Foreigners, in 2016 there were 5,920 permits out of a total of 9,042 positive decisions, this number increased significantly in 2017, amounting to 7,866 out of 13,304 permits (Urząd do Spraw Cudzoziemców, 2016). Altogether, this was the largest group of foreigners, and in the middle of 2016 it totaled 83,490 people (Ostaszewska-Żuk, 2016, p. 24).

In the case of settlers from Ukraine, the trend of temporary migration prevails. It has already been scrutinized that unlike in the case of all migrants, who have changed their place of residence due to economic reasons, women are the dominant gender. While among the total number of employees from Ukraine and the majority of people who 
settle in Poland are men, this tendency does not apply to female Ukrainians. It can be assessed on this basis that the dominant motive for so to speak female settlement in Poland is a marriage to a Polish citizen motif.

In addition, it is clear that for citizens of Ukraine, especially women, Poland became more attractive immediately after joining the EU. Settling and getting married meant being a citizen not only of Poland, but also of the EU. Similarly, after 2016 and the gradual opening of the Polish labor market, we see an increase in the inflow of Ukrainian citizens for permanent residence. Not without significance is the fact that the most significant ease of employment restrictions in relation to them only appeared in 2018. Hence, analogous studies can only be carried out a few years from now.

\section{Cultural and social assimilation - Poles in Norway}

Bearing in mind the issues related to the assimilation of a given group of immigrants in the country of temporary or permanent residence, the authors' assessment should take into account several areas that allow the assessment of the group, regardless of the legal situation of the persons. Assuming objectively that the object of the analysis is persons legally staying and migrating to a given state, one should take into account (a) the axiological plane, connected with the fact of belonging to a religious group that is dominant in a given group. Similarly, (b) the plane associated with the state of consciousness and behavior of individuals and groups assessed within a given community may be significant in the way of perceiving the reality. Also important are (c) social relations between visitors/immigrants and the society/community in which they found themselves. The reasons for integration or alienation may be: (d) family relationships functioning in a given community, identical or not with relations in the country of residence; functioning and dominant (e) mechanisms and relations of an economic nature, perceived as beneficial or not and affecting the material status of immigrants and their families; adaptation to (f) norms and rules operating on the labor market, with temporary immigrants working or permanently employed; and finally, (g) the degree of acceptance and participation in political life, as well as the attitude to dominant norms, constitutional principles and value systems.

In the case of Poles taking up employment in Norway and the decision to reside in this country, language is the biggest barrier to assimilation and the possibility of getting to know native Norwegians. The basic obstacle to assimilation is also the nature of the work and motivation behind the migration. Despite the improving economic situation in Poland, the motives are still economic, related to a desire to ultimately return to Poland (Nowiak, Narożna, Kuhnle, 2016c).

The dominant group among Poles living and working in Norway are men, about $70 \%$. Construction is the predominant employment sector, often the majority of employees carry out a specific construction job. The only Norwegians they encounter in this case are the owners of the construction companies, investors or technical supervisors, who only come into contact with some of the Polish employees working on those construction sites. They are often recruited by intermediaries in Poland, then employed in Norway. Most Poles do not have a command of any foreign languages, this also applies 
to English, because they do not need it. The research proves that, among other things, the functioning of Poles and Polish families in Norway, changes when women start working there and educating their offspring, sending them to local schools.

Referring in more detail to the areas identified at the outset, based on research conducted in Norway, among Poles living and working in this country, the following conclusions can be drawn:

1) the vast majority of Poles are part of the so-called 'Nomadic migration' - they are not interested in integration;

2) they are socially and culturally connected with their group. Many times they live together in houses rented by Norwegian employers (groups from a handful to dozens of people);

3 ) isolation is conducive to the nature of living - due to the above mentioned 'worker residences,' a kind of 'worker hotel;'

4) very often, they do not accept and do not understand many of the standards, principles and institutions commonly accepted by Norwegian society;

5) since most migrants are aware of their temporary stay and the closed nature of Norwegian society, they are not interested in breaking into it;

6) an element conducive to isolation is belonging to different denominational community - Poles are mostly Catholics, while Norwegians are Evangelical Lutherans;

7) a very important obstacle in making decisions about changing economic migration into settlement migration is the climate;

8) more often, partial assimilation occurs among young people who have decided on settlement migration;

9) partial assimilation occurs when the process of children attending kindergartens and schools begins;

10) the children of Poles living with their parents are mostly bicultural, which results in the duality of life/value systems that are often mutually exclusive. There is the syndrome of a child brought as a 'suitcase' - no one asked him whether he wants to go to Norway. Very often there is a sudden break of peer bonds in Poland as well as loss of contact with grandparents and other family members. Children are angry at their parents, but they have no choice. These ties are renewed when organizing, for example, First Communions, very often in Poland;

11) the importance of traditional, integration institutions is decreasing, they are being replaced by websites and social networking sites;

12) a significant part of Poles feel a sense of discrimination due to the Norwegian asylum policy, which additionally encourages alienation;

13) Poles accept and follow patterns in the field of standards and rules operating in Norwegian work environments;

14) Poles do not accept Norwegian work culture, where there is a place for rest and due breaks or benefits;

15) Poles, despite the formal possibilities of participating in the life of local communities of a self-governing nature, do not get involved in their lives.

As can be seen from the above-mentioned partial conclusions, due to the nature of the labor migration prevailing among Poles and the character of the Norwegian national community, the assimilation of Poles migrating to Norway is mainly of a formal nature. 
It manifests itself mainly in the sphere of work (legality of employment) and access to the social system.

\section{Cultural and social assimilation - Ukrainians in Poland}

A great convenience for Ukrainian citizens coming to work in Poland and deciding on migrations is their knowledge of the Polish language, as well as the closeness and similarity of the Polish, Ukrainian and Russian languages. This is related to the historical ties of Western Ukraine with Poland. Before World War II, it was part of Poland, and to this day many residents of this part of the country use this language or have relatives or friends who identify with their Polish roots.

As research indicates, half of Ukrainians come to Poland to work for 1-3 months. During talks with the Ukrainian research agency Rating Group, which cooperated in the creation of the Barometer (400 citizens of Ukrainian origin working in Poland were questioned), the Ukrainians admitted that they treated their stay in Poland as an opportunity for short-term earnings. They emphasized that they chose Poland as a profit-making destination, because it is close. Thanks to this, they can quickly return home when they need to. They are also compensated by local earnings ( $44 \%$ of respondents). In Poland, a Ukrainian earns an average of four times more than in their own country. During their stay, they try to spend as little as possible. They put savings aside and take them back to their home country. Ukrainians gather funds and then take them to their homeland, when their visa expires, rather than sending back a specific sum every month. In this way, they avoid fees for international bank transfers (Większość Ukraińców..., 2018). The situation of Ukrainian citizens is similar to that in which Poles found themselves in the association period with and in the case of EEA countries in transition periods. Hence, research into their presence and levels of assimilation are not fully comparable to the conditions in which Poles currently operate in Norway, although similarities are visible in many areas due to the typically commercial nature of the migration.

Referring in more detail to the areas of assimilation under analysis in relation to Poles migrating to Norway, and on the basis of the experience and lessons learned from the presence of Ukrainian citizens in Poland, the following conclusions can be drawn for each of them.

I. The axiological plane, associated with the fact of belonging to the dominant religious group in a given community. Most Ukrainians who come to Poland are Orthodox believers. The system of values, the functioning of societies covered by Orthodoxy and Catholicism, is not so divergent.

II. The plane associated with the state of consciousness and behavior of individuals and groups assessed within a given community may be significant in the way of perceiving the reality. In the case of Poles and Ukrainians, there are no major socio-cultural differences in the perception of reality in terms of the behavior of both communities.

III. Social relations between newcomers/immigrants and the society/community in which they found themselves. There is a noticeable difference in the approach to Ukrainians depending on the nature of contacts, or their absence and the situation on the local labor market, e.g. unemployment rates. 
IV. Family relationships functioning in a given community, identical or not with relationships in the state of residence. In this case, there are no significant differences, both communities are characterized by the traditional patriarchal character of families and the same approaches to children, their rights and duties.

$V$. Mechanisms and relations of an economic nature, perceived as beneficial or not and affecting the material status of immigrants and their families.

VI. Norms and rules operating on the labor market, with temporary immigrants or those permanently employed. Employees from Ukraine functioning on the Polish labor market, in addition to equal treatment in terms of remuneration, benefit from the same regulations regarding norms and principles of labor law and social protection as employees from Poland.

VII. The degree of acceptance and participation in political life, as well as the attitude to dominant norms, constitutional principles and value systems. Due to the nature of their stay, the relatively frequent changes of regulations regarding their employment and seasonality, there is no possibility of their wider participation in social life. They also do not have political rights with regard to the possibility of participation in local elections.

The conclusions drawn both on the basis of qualitative and quantitative research in relation to immigrants from Ukraine residing and working in Poland indicate the greater probability of their assimilation. This depends on the progressive suppression of their stay and work and the extension of social legislation to their family members.

Much now depends on the situation in Ukraine, especially the stabilization processes and the possible return of Poles residing abroad. Ukrainians feel at home in Poland as it facilitates cultural and linguistic proximity, which is also connected with the fact that the majority of those who come to Poland also speak Russian. This language is known to many Polish citizens, hence the ease of communication. This fact often causes that Ukrainians, despite lower salaries, choose Poland, not Germany as their destination of migration.

\section{Conclusions}

As can be seen from the above analysis, economic considerations are the main motive for the migration of both communities. In the case of Ukrainian citizens, the internal crisis connected with the conflict over the part of the country that is in a state of civil war is also very important.

Poles and Ukrainians are not at the same stage of formal migration due to the formal plane. The scope of their rights is not the same. The gap created by the absence of millions of Poles, working abroad, in Norway, among other places, is filled by Ukrainian citizens. They have far greater opportunities for actual assimilation than Poles in Norway. If the state and Polish society take advantage of this situation and enable the settlement of Ukrainians and make their job offers more attractive, there is a chance that they will fill the emerging demographic gap.

In a few years, Poles became the second largest national group in Norway, the largest minority that has developed from only several thousand people in the early twentieth 
century. Ukrainians are one of the largest national minorities in Poland, and they have a chance of occupying a similar place in Poland as Poles in Norway.

As can be seen from the analysis of the assimilation planes, the feasibility of this prognosis is very high.

\section{Bibliography}

“Aftenposten”, Lørdag 26. april 2014.

Brox O. (2005), Arbeidskraftimport: velferdsstatens redning - eller undergang?, Pax, Oslo.

Czop E. (2013), Migranci polscy w krajach unijnej piętnastki (1992-2011). Wybrane zagadnienia, Rzeszów.

Friberg J. H., Eldring L. (2011), Polonia i Oslo 2010. Mobilitet, arbeid og levekår blant polakker $i$ hovedstaden, Fafo-rapport 2011:27.

Frieberg J. H., Elgvin O., Djuve A. B. (2013), Innvandrerne som skulle klare seg selv, Fafo-rapport 2013:3.

Innvandrere og norskfødte med innvandrerforeldre, 1. januar 2015, https://www.ssb.no/befolkning/statistikker/innvbef/aar/2015-03-04, 15.06.2015.

Kaczmarczyk P. (2008), Wspótczesne migracje z Polski - próba oceny statystycznej zjawiska, in: Wspótczesne migracje zagraniczne Polaków. Aspekty lokalne i regionalne, ed. P. Kaczmarczyk, Wyd. Ośrodek Badań nad Migracjami, Warszawa.

Kersten K. (1974), Repatriacja ludności polskiej po II wojnie światowej. Studium historyczne, Wyd. Ossolineum, Wrocław.

Landman T., Robinson N. (2009), The SAGE Handbook of Comparative Politics, SAGE.

Migracje Zarobkowe Polaków, VII, (2017), Work Service.

Nowiak W. (2011), Nordycki model ,, welfare state” w realiach XXI wieku. Dylematy wyboru i ewolucja systemu w społeczeństwach dobrobytu - wnioski praktyczne, Poznań.

Nowiak W., Narożna D., Cappelen C. (2016a), Migracja wewnętrzna w UE oraz EOG a problem nielegalnego rynku pracy. Analiza sytuacji imigrantów z Polski zamieszkujących okręg Hordaland, „Przeglad Politologiczny” (Political Science Reviev), no. 3.

Nowiak W., Narożna D., Kuhnle S. (2016c), Rodzina migracyjna. Obraz rodziny na podstawie badań polskich imigrantów w Norwegii, (Migrants families. The experiences of Poles in Norway), "Prace Naukowe Uniwersytetu Ekonomicznego we Wrocławiu" (Research Papers of Wrocław University of Economy), 438/2016.

Nowiak W., Narożna D., Murrias R. L. (2016b), Nordycki model wspierania rodzin niewydolnych $w$ opiece nad dzieckiem. Analiza sytuacji Polaków oraz ich rodzin w Norewgii, „Prace Naukowe Uniwersytetu Ekonomicznego we Wrocławiu” (Research Papers of Wrocław University of Economy), 456/2016.

NOU: 2011:7, Velferd og migrasjon. Den norske modellens framtid.

Okólski M. (1994), Migracje zagraniczne w Polsce w latach 1980-1989. Zarys problematyki badawczej, "Studia Demograficzne," nr 3, Warszawa.

Ostaszewska-Żuk E. (2016), Cudzoziemcy w Polsce. Podręcznik dla funkcjonariuszy publicznych, Warszawa.

Urząd do Spraw Cudzoziemców, Statystyki - Zestawienia roczne, http://udsc.gov.pl/statystyki/raportyokresowe/zestawienia-roczne/, 27.09.2016.

Weiss R. S. (1995), Learning from strangers. The Art and Method of Qualitative Interview Studies, The Free Press. 
Większość Ukraińców chce przyjechać do pracy w Polsce na krótko i jak najmniej wydać na miejscu (2018), https://businessinsider.com.pl/finanse/ukraincy-pracujacy-w-polsce-barometrimigracji-zarobkowej-2018/t9ftrbb, 22.06.2018.

Kulturowa i społeczna asymilacja imigrantów a rozwiązania systemowe - Polacy w Norwegii i Ukraińcy w Polsce, w świetle badań porównawczych

\section{Streszczenie}

Przedmiotem analizy jest problem migracji oraz asymilacji przybyszów w krajach pobytu. Jednym z głównych powodów migracji są względy o charakterze ekonomicznym i społecznym, dotyczy to zarówno przybyszów spoza Europy, jak i migracji wewnętrznej. Celem badania przeprowadzonego przez uczonych z Norwegii oraz Polski jest porównanie rozwiązań systemowych zarówno w obrębie prawodawstwa socjalnego, jak i funkcjonowania rynku pracy w odniesieniu do Polaków oraz Ukraińców. Skonfrontowanie ich z istniejącymi barierami dotyczącymi możliwości asymilacji oraz przeszkód związanych z przekształceniem migracji zarobkowej w osiadłą. Podstawę metodologiczno-teoretyczną zespołu stanowią metody komparatystyczne. Badania dotyczące imigrantów, prowadzone zostały przy użyciu metod zarówno ilościowych - analizy danych statystycznych, jak i jakościowych. Polacy i Ukraińcy nie znajdują się z uwagi na płaszczyznę formalną na tych samych etapach migracji, zakres ich praw nie jest taki sam. Jak wynika z przeprowadzonej analizy, Ukraińcy mają dużo większe możliwości faktycznej asymilacji w Polsce niż Polacy w Norwegii. Sprzyjają temu procesowi mniejsze różnice kulturowe oraz bariery językowe w odniesieniu do Ukraińców w Polsce. Jeśli państwo i społeczeństwo polskie wykorzystają tę sytuację i umożliwią osiedlanie się Ukraińców, a także uatrakcyjnią im oferty pracy, istnieje szansa, iż wypełnią oni powstającą lukę demograficzną. Byłoby to z korzyścią dla obu społeczeństw.

Słowa kluczowe: migracja, asymilacja migrantów, Polacy w Norwegii, Ukraińcy w Polsce 